\title{
Capturing urine while maintaining pasture intake, milk production, and animal welfare of dairy cows in early and late lactation
}

\author{
C. E. F. Clark, ${ }^{* 1}$ K. L. M. McLeod, ${ }^{*}$ C. B. Glassey, ${ }^{*}$ P. Gregorini, ${ }^{*}$ D. A. Costall, $†$ K. Betteridge, $†$ and J. G. Jago* \\ *DairyNZ Ltd., Private Bag 3221, Hamilton 3240, New Zealand \\ †AgResearch Grasslands, Private Bag 11008, Palmerston North 4442, New Zealand
}

\begin{abstract}
Capturing urine and spreading it evenly across a paddock reduces the risk of nitrogen loss to the environment. This study investigated the effect of $16 \mathrm{~h} / \mathrm{d}$ removal from pasture on the capture of urination events, milk production, pasture intake, and animal welfare from cows grazing fresh pasture in early and late lactation. Forty-eight Holstein-Friesian cows in early $[470 \pm 47$ $\mathrm{kg}$ of body weight (BW); $35 \pm 9$ days in milk] and late (498 $\pm 43 \mathrm{~kg}$ of BW; $225 \pm 23$ days in milk) lactation were allocated to 3 treatment groups. Cows had access to pasture for either $4 \mathrm{~h}$ after each milking $(2 \times 4)$, for $8 \mathrm{~h}$ between morning and afternoon milkings $(1 \times 8)$, or for $24 \mathrm{~h}$, excluding milking times (control). When not grazing, the $2 \times 4$ and $1 \times 8$ groups were confined to a plastic-lined loafing area with a woodchip surface. In early lactation, the proportion of urinations on pasture and laneways was reduced from $89 \%$ (control) to $51 \%$ $(1 \times 8)$ and $54 \%(2 \times 4)$ of total urinations. The $1 \times 8$ cows ate less pasture $[10.9 \mathrm{~kg}$ of dry matter $(\mathrm{DM}) / \mathrm{cow}$ per day] than the control (13.6 $\mathrm{kg}$ of $\mathrm{DM} /$ cow per day) and $2 \times 4(13.0 \mathrm{~kg}$ of $\mathrm{DM} /$ cow per day) cows, which did not differ from each other. The $1 \times 8$ and $2 \times 4$ cows produced less milk (21 and $22 \mathrm{~kg}$ of milk/cow per day, respectively) compared with control cows (24 kg of milk/cow per day). There were no differences in BW or body condition score (BCS) change across treatment groups, with all groups gaining BW and BCS during the experimental period. In late lactation, there was no difference in pasture intake (mean $=8.8 \mathrm{~kg}$ of $\mathrm{DM} /$ cow per day), milk production (mean $=10 \mathrm{~kg}$ of milk $/$ cow per day), and BW or BCS change (mean $=3.7 \mathrm{~kg}$ and $-0.2 \mathrm{U} /$ cow per week, respectively) between treatment groups. As in early lactation, urinations on pasture and laneways were reduced from $85 \%$ (control) to $56 \%(1 \times$ $8)$ and $50 \%(2 \times 4)$ of total urinations. These findings
\end{abstract}

Received November 12, 2009.

Accepted January 17, 2010.

${ }^{1}$ Corresponding author: cameron.clark@dairynz.co.nz highlight an opportunity to maintain performance and welfare of grazing cows in early and late lactation while capturing additional urine. This can subsequently be spread evenly across pasture to minimize nitrogen loss to the environment.

Key words: restricted grazing, urine capture, animal production

\section{INTRODUCTION}

In grazed pastures, the potential for nitrate leaching increases significantly compared with mown pasture without animals as only 10 to $40 \%$ of the $\mathrm{N}$ ingested by the grazing animal is removed in animal product (Haynes and Williams, 1993; Jarvis et al., 1995). Of ingested N, 70\% is returned in urine to the soil-pasture system (Haynes and Williams, 1993), and this is the major source of $\mathrm{N}$ leached from farmland into water sources (Jonker et al., 1998). This is particularly true for urine deposited on pasture in late autumn and winter, which coincides with the main period of soil water drainage (Ledgard and Menneer, 2005). Capturing this urine on a loafing area and spreading it evenly across pastures would potentially reduce the risk of $\mathrm{N}$ loss to the environment (Di and Cameron, 2002; Lindsay et. al., 2009).

In pastoral dairy production systems, time on pasture is reduced by on-off grazing during wet soil conditions to maintain pasture production and utilization by reducing treading damage (Blackwell, 1993). Previous studies with dairy and beef cattle indicate that there may be an opportunity to reduce time on pasture and still maintain DMI and production (Kristensen et al., 2007; Perez-Ramerez et al., 2008; Kennedy et al., 2009), with animals adjusting their grazing behavior to compensate for time restrictions at pasture by increasing herbage intake rate.

Therefore, our objectives were to capture urine by strategically confining cows off pasture and then to determine what effect this might have on pasture intake and milk production for early- and late-lactation cows. 


\section{MATERIALS AND METHODS}

\section{Site, Animals, and Treatments}

The study was conducted as 2 experiments at Scott Farm, DairyNZ, Hamilton, New Zealand $\left(37^{\circ} 47^{\prime} \mathrm{S}\right.$, $\left.175^{\circ} 19^{\prime} \mathrm{E}\right)$ : experiment $1=$ early lactation $(\mathbf{E L})$, September 13 to October 3, 2008; experiment 2 = late lactation (LL), April 9 to 24, 2009. Both experimental periods followed a 10-d adaptation period to treatments. All animal experimentation was approved by the Ruakura Animal Ethics Committee (Hamilton, New Zealand).

Forty-eight mixed age, multiparous Holstein-Friesian cows in early $(470 \pm 47 \mathrm{~kg}$ of BW; $35 \pm 9$ DIM) and late (498 $\pm 43 \mathrm{~kg}$ of BW; $225 \pm 23$ DIM) lactation were assigned to 6 groups ( $\mathrm{n}=8$ cows/group) balanced for calving date, milk yield, milksolids yield, and BW and were grazed according to the following treatments (2 groups per treatment): pasture grazing offered for $4 \mathrm{~h}$ after each milking $(\mathbf{2} \times \mathbf{4})$, for $8 \mathrm{~h}$ between morning and afternoon milkings $(\mathbf{1} \times \mathbf{8})$, or for $24 \mathrm{~h}$, excluding milking times (control). Between grazing periods, the $1 \times 8$ and $2 \times 4$ cows were confined to a plastic-lined loafing area with a woodchip surface located $1.2 \mathrm{~km}$ from the grazing area and $500 \mathrm{~m}$ from the dairy.

\section{Pasture and Grazing Management}

Early Lactation Study. Cows were grazed on 11 ha of perennial ryegrass-dominant pasture (Lolium perenne L., 80\%; Trifolium repens, 3\%; Poa annua and trivialis, $7 \%$; and broadleaf weeds, 10\%). Grazing management before the start of the trial was similar between plots per the decision rules of Macdonald and Penno (1998), with perennial ryegrass-dominant swards grazed at $2,500 \mathrm{~kg}$ of $\mathrm{DM} / \mathrm{ha}$ in spring, 4,000 $\mathrm{kg}$ of $\mathrm{DM} / \mathrm{ha}$ in summer, and $3,000 \mathrm{~kg}$ of DM/ha in autumn and winter (all DM measurements were to ground level). Postgrazing residual stubble heights were approximately 40 $\mathrm{mm}$ in height during winter and spring and $60 \mathrm{~mm}$ during summer and autumn.

Treatment groups were allocated pasture daily, at random, in adjacent $830 \mathrm{~m}^{2}$ plots after the morning milking. An estrus synchrony program using controlled internal release devices (InterAg, Hamilton, New Zealand) was implemented on August 27 to ensure that cows did not express estrus during the experimental period. Pasture chemical composition was DM, $14 \%$; OM digestibility (OMD), 87\%; CP, 20\%; ADF, 23\%; NDF, $42 \%$; and ash, $10 \%$. The control and $2 \times 4$ treatment groups returned to the morning grazing allocation for their second grazing period after the evening milking. Grazed pasture was the sole feed type offered.
On average, each cow had a $20-\mathrm{m}^{2}$ loafing area. Cows had unlimited access to water on both the pasture and loafing area.

Late Lactation Study. Cows were grazed on 11 ha of perennial ryegrass-dominant pasture (Lolium perenne L., 67\%; Trifolium repens, 7\%; Poa annua and trivialis, $16 \%$; and broadleaf weeds, 10\%). Treatment groups were randomly allocated to adjacent $830 \mathrm{~m}^{2}$ pasture plots daily after the morning milking. Herbage chemical composition was DM, 20\%; OMD, 76\%; CP, 19\%; $\mathrm{ADF}, 26 \%$; NDF, $44 \%$; and ash, $10 \%$.

\section{Measurements and Calculations}

Pasture Measurements. Pre- and postgrazing heights were measured daily using an electronic rising plate meter (360 mm diameter, $315 \mathrm{~g}$ plate weight; Farmworks Ltd., Fielding, New Zealand). Eighty pasture heights were measured in each treatment plot for EL and LL. Pasture mass was subsequently determined using the following equation in EL: compressed height (in $0.5 \mathrm{~cm}) \times 140+500$ (L'Hullier and Thomson, 1988). Pasture mass was determined from weekly calibration cuts in LL. The multiplier and adder to determine pasture mass from compressed height for wk 1, 2, and 3 of the LL experimental period were 196 and 1,190, 193 and 1,530, and 116 and 1,020, respectively.

Animal Measurements. Herbage intakes per group of animals were estimated daily from pre- and postgrazing pasture mass (Walters and Evans, 1979). Each water trough was fitted with a flow meter to determine water imbibed in group pasture and the loafing area. Milk yield for each cow was determined at each milking. Milk fat and protein concentration and SCC (Fossomatic, Foss Electric, Hillerød, Denmark) were determined weekly for each cow. Body weight and BCS, on a scale 1 to 10 (Macdonald and Roche, 2004), were recorded weekly after the morning milking. Locomotion score was measured weekly on a scale of 1 to $5(1=$ normal gait, 5 = severely lame; O'Callaghan and Downham, 2003). IceTag3D motion sensors (IceRobotics, Edinburgh, UK) were used on each cow to determine the number of steps taken and the corresponding kilometers walked each day, as validated by McGowan et al. (2007). For cows in EL, weekly milk samples were analyzed for individual cow MUN concentration (mmol/L: Gribbles Veterinary Laboratory, Hamilton, New Zealand). Cow MUN was not determined in LL. Urinary nitrogen concentration $(\mathrm{mmol} / \mathrm{L})$ was estimated using the formula $0.026 \times$ MUN $(\mathrm{mg} / \mathrm{dL}) \times$ BW (Kohn et al., 2002)

Urinations. The distribution of urinations over $48 \mathrm{~h}$ in 2 separate weeks of each experiment were determined using urine sensors (AgResearch, Palmerston North, New Zealand) described and validated by K. Betteridge 
Table 1. Pasture and milk production measures from herds grazed in early or late lactation for two 4 -h periods after each milking $(2 \times 4)$, one 8-h period between milking $(1 \times 8)$, and at times other than milking (control)

\begin{tabular}{|c|c|c|c|c|c|c|c|c|}
\hline \multirow[b]{2}{*}{ Item } & \multicolumn{4}{|c|}{ Early lactation } & \multicolumn{4}{|c|}{ Late lactation } \\
\hline & Control & $1 \times 8$ & $2 \times 4$ & $\mathrm{SE}$ & Control & $1 \times 8$ & $2 \times 4$ & $\mathrm{SE}$ \\
\hline Pasture intake (kg of DM/cow per day) & $13.6^{\mathrm{a}}$ & $10.9^{\mathrm{b}}$ & $13.0^{\mathrm{ab}}$ & 0.6 & 10.8 & 9.6 & 10.4 & 0.4 \\
\hline Pregrazing sward height ${ }^{1}(\mathrm{~cm})$ & 9.8 & 9.4 & 9.7 & 0.2 & 7.1 & 7.0 & 7.0 & 0.2 \\
\hline Postgrazing sward height ${ }^{1}(\mathrm{~cm})$ & $5.2^{\mathrm{a}}$ & $6.0^{\mathrm{b}}$ & $5.2^{\mathrm{ab}}$ & 0.1 & 4.4 & 4.6 & 4.5 & 0.1 \\
\hline Fat $(\%)$ & 4.1 & 4.3 & 4.1 & 0.1 & 5.5 & 5.5 & 5.8 & 0.1 \\
\hline Protein (\%) & 3.5 & 3.4 & 3.4 & 0.1 & 4.1 & 4.3 & 4.1 & 0.1 \\
\hline
\end{tabular}

${ }^{\text {a-c }}$ Means within a row with different superscripts are significantly different $(P<0.05)$.

${ }^{1}$ Compressed height by plate meter.

${ }^{2} \mathrm{MS}=$ milksolids

(unpublished data). On average, urine sensor data were obtained from 2 cows per group of animals. A global positioning system collar was fitted to $1 \mathrm{cow}$ in each replicated treatment group to monitor the cow's location (pasture, laneway, loafing pad, milking) when she urinated. Urinations were classified as captured if they occurred on the loafing pad and dairy yards, or uncaptured if on pasture and laneways by synchronizing time on the urine sensors and global positioning system collars to relate urinations with location.

Cow Welfare. An animal is described as having good animal welfare if it is healthy, comfortable, well nourished, safe, able to express innate behavior, and not suffering from unpleasant states such as pain, fear, and distress (World Organisation for Animal Health, 2008). For the purpose of this study, the effect of the treatments imposed on welfare factors was determined by monitoring BW, BCS, and production traits, including SCC and lameness assessed by locomotion score.

\section{Statistical Analysis}

Repeated measurements were analyzed using the method of summary statistics (Rowell and Walters, 1976) by calculating separate summary measures for each group in EL and LL, after $\log _{10}$ transformation of SCC, and then analyzing these using ANOVA in Genstat (Payne et al., 2008). In this analysis, treatment was a fixed effect and group was a random effect.

\section{RESULTS}

\section{Weather}

For the experimental period in EL, mean rainfall was $2.5 \mathrm{~mm} / \mathrm{d}(30-\mathrm{yr}$ mean $=3 \mathrm{~mm} / \mathrm{d})$; air temperature was $12^{\circ} \mathrm{C}\left(30\right.$-yr mean $\left.=12^{\circ} \mathrm{C}\right)$, and mean total sun- shine hours were $6 \mathrm{~h} / \mathrm{d}(30-\mathrm{yr}$ mean $=6 \mathrm{~h} / \mathrm{d})$. For the experimental period in LL, rainfall was $2 \mathrm{~mm} / \mathrm{d}(30-\mathrm{yr}$ mean $=3 \mathrm{~mm} / \mathrm{d})$, air temperature was $16^{\circ} \mathrm{C}(30-\mathrm{yr}$ mean $=16^{\circ} \mathrm{C}$ ), and total sunshine hours were $8 \mathrm{~h} / \mathrm{d}$ $(30-\mathrm{yr}$ mean $=6 \mathrm{~h} / \mathrm{d})$.

\section{Early Lactation Study}

Over the EL experimental period, each group of animals was allocated the same area and daily herbage allowance of $33 \mathrm{~kg}$ of $\mathrm{DM} /$ cow (mean pregrazing cover $=$ approximately $3,190 \mathrm{~kg}$ of $\mathrm{DM} / \mathrm{ha} ; P=0.25$; Table 1). The $1 \times 8$ treatment left a greater $(P<0.01)$ postgrazing pasture mass than the control or $2 \times 4$ groups. Pasture intake was less $(P=0.04)$ for the $1 \times$ 8 treatment than for the control; however, $2 \times 4$ cow intake was similar $(P=0.46)$ for control and $1 \times 8$ cow intakes.

Milk, fat, and protein production $(\mathrm{kg} / \mathrm{cow})$ were less for the $1 \times 8(P<0.01)$ and $2 \times 4(P=0.02)$ treatments than for the control (Table 1). There were no differences in fat and protein concentration across treatments.

There was no difference in the number of urinations per day (mean $=14$ urinations/d) or the frequency of urinations on pasture and laneways (mean $=0.68$ urinations $/ \mathrm{h})$ across treatment groups $(P=0.97)$ or MUN $(P=0.44)$ during the experimental period (Table 2 ). Consequently, the percentage of urinations deposited on pasture and laneways was significantly less for the $1 \times 8$ and $2 \times 4$ treatments relative to the control. The proportion of urinations on pasture and laneways were reduced $(P=0.03)$ from $89 \%$ (control) to $51 \%$ (1 $\times 8)$ and $54 \%(2 \times 4)$.

There were no differences in BW $(P=0.77)$, BCS change $(P=0.54)$, or $\log _{10} \operatorname{SCC}(P=0.15)$ between treatments, with all cows gaining $\mathrm{BW}$ and BCS during 
Table 2. Environmental measures from herds grazed in early or late lactation for two 4 -h periods after each milking $(2 \times 4)$, one 8 -h period between milking $(1 \times 8)$, and at times other than milking (control)

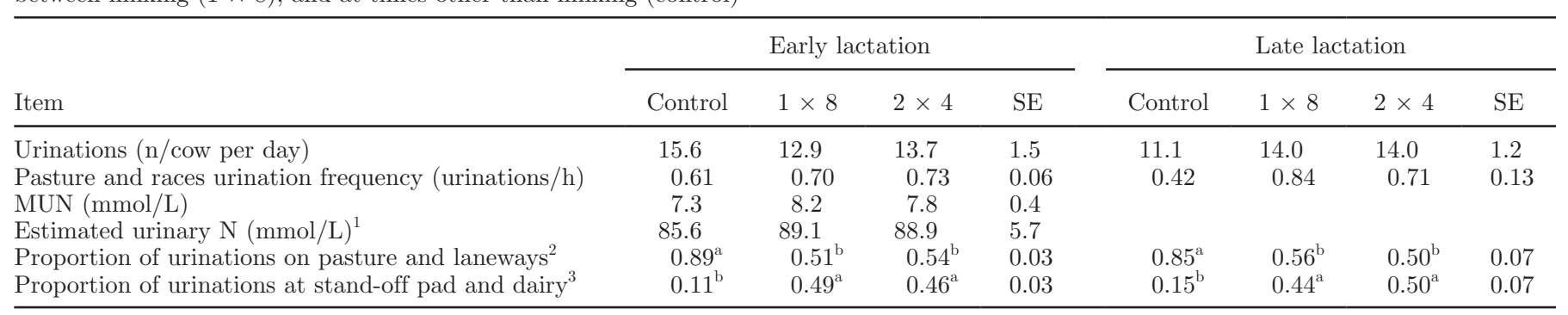

${ }^{\mathrm{a}, \mathrm{b}}$ Means within a row with different superscripts are significantly different $(P<0.05)$.

${ }^{1}$ Estimated as $0.26 \times$ MUN $\times$ BW (Kohn et al., 2002).

${ }^{2}$ Uncaptured urine.

${ }^{3}$ Captured urine.

the experimental period (Table 3 ). The $2 \times 4$ treatment group walked the greatest distance per day, an average of $5.9 \mathrm{~km} /$ cow per day. This was $1.2 \mathrm{~km}$ more $(P<$ $0.01)$ than the control cows. The $1 \times 8$ cows walked an average of $1.1 \mathrm{~km} /$ cow per day $(P<0.01)$ less than control. In the first week of the experiment, the $2 \times$ 4 cows had a greater mean locomotion score than the control and $1 \times 8$ groups. Two cows with a locomotion score of 3 were removed from the $2 \times 4$ treatment on the advice of the veterinarian due to preexisting conditions. Two replacement cows were introduced to the $2 \times$ 4 treatment to maintain similar cow numbers between treatments but were excluded from all measurements. For the remainder of the trial there was no difference in locomotion score across the treatments $(P=0.33)$. Mean water intakes (approximately $24 \mathrm{~L} /$ cow per day; $P=0.19)$ were similar between treatment groups.

\section{Late Lactation Study}

Over the LL experimental period, each replicate was allocated the same area and daily herbage allowance of $38 \mathrm{~kg}$ of $\mathrm{DM} /$ cow (mean pregrazing cover $=$ approxi- mately $3,654 \mathrm{~kg}$ of $\mathrm{DM} /$ ha; $P=0.78$; Table 1$)$. There was no difference in postgrazing pasture mass (mean postgrazing pasture cover $=$ approximately $2,835 \mathrm{~kg}$ of $\mathrm{DM} / \mathrm{ha} ; P=0.13$ ) and, therefore, pasture intake between treatments.

There was no significant difference in LL milk yield or fat and protein production $(\mathrm{kg} / \mathrm{cow})$ and fat and protein content (Table 1 ).

There was no difference in the number of urinations per day $($ mean $=13$ urinations $/$ d) or the frequency of urination events on pasture and laneways $($ mean $=0.66$ urinations/h) across LL treatment groups (Table 2). Consequently, the percentage of urinations deposited on pasture and laneways was significantly less for the 1 $\times 8$ and $2 \times 4$ treatments relative to the control. The percentage of urination events on pasture and laneways was reduced from $85 \%$ (control) to $56 \%(1 \times 8)$ and $50 \%(2 \times 4)$.

Body weight, BCS change, and $\log _{10}$ SCC in LL were similar between treatments, with all cows gaining BW $(3.7 \mathrm{~kg} /$ cow per week) and losing BCS $(-0.2 \mathrm{U} /$ cow per week) during the experimental period (Table 3 ). The $2 \times 4$ and control cows walked further (6.0 and 4.8

Table 3. Welfare measures from herds grazed in early or late lactation for two 4-h periods after each milking $(2 \times 4)$, one 8 -h period between milking $(1 \times 8)$, and at times other than milking (control)

\begin{tabular}{|c|c|c|c|c|c|c|c|c|}
\hline Item & \multicolumn{4}{|c|}{ Early lactation } & \multicolumn{4}{|c|}{ Late lactation } \\
\hline BW change (kg/cow per week) & 3.0 & 2.8 & 4.4 & 0.3 & 3.9 & 1.3 & 6.0 & 1.6 \\
\hline $\log _{10} \mathrm{SCC}($ cells $/ \mathrm{mL})$ & 2.0 & 1.7 & 2.0 & 0.1 & 2.1 & 2.5 & 2.0 & 0.1 \\
\hline Steps $(\mathrm{n} / \text { cow per dav })^{1}$ & $5.326^{\mathrm{b}}$ & $4.029^{\mathrm{c}}$ & $6.670^{\mathrm{a}}$ & 102 & $5.383^{\mathrm{b}}$ & $4.430^{\mathrm{b}}$ & $6.752^{\mathrm{a}}$ & 314 \\
\hline Distance walked (km/cow per day) & $4.7^{\mathrm{b}}$ & $3.6^{\mathrm{c}}$ & $5.9^{\mathrm{a}}$ & 0.1 & $4.8^{\mathrm{b}}$ & $3.9^{\mathrm{b}}$ & $6.0^{\mathrm{a}}$ & 0.3 \\
\hline
\end{tabular}

${ }^{\mathrm{a}-\mathrm{c}}$ Means within a row with different superscripts are significantly different $(P<0.05)$.

${ }^{1}$ Excludes lame cows removed in the first week of the experimental period.

${ }^{2}$ Locomotion score was measured weekly on a scale of 1 to 5 ( 1 = normal gait; $5=$ severely lame). 
$\mathrm{km} /$ cow per day, respectively; $P=0.02)$ than the $1 \times$ 8 cows $(3.9 \mathrm{~km} /$ cow per day; $P=0.03)$. Locomotion scores and water imbibed were similar $(P=0.80$ and $P$ $=0.86$, respectively) between treatments.

\section{DISCUSSION}

The experiments within this study show that increasing the time spent off pasture can reduce $\mathrm{N}$ loss to the environment at high-risk times while maintaining cow production and welfare. These findings enhance understanding of cow production and the location of urinations when access to fresh pasture is restricted.

\section{Urinations}

Despite the changes in grazing behavior associated with restricting access to pasture (Gregorini et al., 2009), the urination frequency while on pasture and races did not differ for the control and both restricted grazing treatments between EL (mean $=0.68$ urinations $/ \mathrm{h})$ and LL (mean $=0.66$ urinations $/ \mathrm{h})$. The similarity in urination frequency associated with control and restricted grazing access in the current trial is consistent with the findings of Oudshoorn et al. (2007), who showed no difference in urination frequency per hour (mean $=$ 0.26 urinations $/ \mathrm{h}$ ) when time on pasture was reduced from 9 to $4 \mathrm{~h}$. Together, the 2 studies indicate that the frequency of urinations, for cows offered the same feed type, is independent of the timing and the duration over which feed is offered.

The lower mean frequency of 0.26 urinations $/ \mathrm{h}$ found by Oudshoorn et al. (2007) compared with 0.67 urinations/h for the current study suggests there are factors, other than the time that feed is offered, driving differences in urination frequency. The amount of water ingested in feed is likely a key driver of urination frequency because approximately $50 \%$ of the total intake in the study of Oudshoorn et al. (2007) was a supplementary feed mixture of approximately $45 \%$ DM. Betteridge et al. (1986) reported greater water intake and urination frequency by steers on a hot day compared with on a cool day. In the present trial, however, the greater water intake by cows in LL was not reflected in a greater urination frequency than cows in EL, possibly because of differences in the amount of water derived from feed. At a pasture DM content of $14 \%$ in EL and $20 \%$ in LL, cows in the current study ingested approximately 89 and $44 \mathrm{~L}$ of water in feed and drank 24 and $34 \mathrm{~L} /$ cow per day (total $=113$ and $77 \mathrm{~L} /$ cow per day) in EL and LL, respectively.

Given the reduction of time on pasture for the $1 \times 8$ and $2 \times 4$ treatments, and similar urination frequency between the treatments, the percentage of uncaptured urinations (i.e., those on pasture and laneways) for EL and LL cows was reduced from approximately 90 to $50 \%$ when grazing access was restricted to $8 \mathrm{~h}$ between the morning and evening milkings. When the 10 to $20 \%$ of urinations that occurred on the laneways in the current study are accounted, this proportion of urinations on pasture is similar to those presented by Hardison et al. (1956), who reported that 30 to $40 \%$ of a lactating dairy cow's total urinations were deposited onto pasture between the morning and evening milkings.

The substantial increase in captured urine in the current trial has major implications for $\mathrm{N}$ leaching loss and is consistent with previously reported reduction with continuous use of a loafing pad during winter (de Klein and Ledgard, 2001).

\section{DMI and Milk Production}

In response to restricted grazing access, EL cows in the $2 \times 4$ and $1 \times 8$ treatments attempted to maintain DMI by modifying their grazing behavior (Gregorini et al., 2009); this is consistent with previous studies (Kristensen et al., 2007; Perez-Ramerez et al., 2008; Kennedy et al., 2009). However, restricting grazing to 1 continuous 8 -h period between morning and afternoon milkings $(1 \times 8)$ resulted in a lower DMI $(10.9 \mathrm{~kg}$ of $\mathrm{DM} /$ cow per day) than when cows had unrestricted grazing (control; $13.6 \mathrm{~kg}$ of DM/cow per day). Consistent with reduced DMI, the EL $1 \times 8$ cows had lower milk production when compared with control cows $(20.8$ vs. $24.0 \mathrm{~kg} /$ cow per day, respectively). The lower DMI and milk production of EL $1 \times 8$ cows, compared with control cows, is consistent with the findings of Hutton and Parker (1966), who concluded that "...even under conditions of abundant pasture, it is not possible for grazing animals in early lactation to obtain in 8 hours all the feed they need to reach peak (milk) production." However, when pasture was offered as $2 \times 4 \mathrm{~h}$ periods in the current study, pasture DMI was maintained relative to the control. These findings are consistent with those of Kennedy et al. (2009), who reported that cows restricted to 1 grazing of $9 \mathrm{~h} / \mathrm{d}$ had lower total DMI compared with the control cows. However, when this 9-h period was split into 2 periods of $4.5 \mathrm{~h}$, total DMI was maintained compared with the control.

Splitting the time that pasture is offered into 2 periods presumably reduces hunger as this is related to the number of hours since the last meal (Forbes, 1995). The response to hunger is to increase eating time when feed is next offered (Chilibroste et al., 2004). In this respect, behavioral observations and hormonal and metabolic data (Gregorini et al., 2009) indicate that the $1 \times 8$ cows were motivated to eat for a longer percentage of the first 4-h grazing period (81\%) compared with $2 \times$ 
$4(68 \%)$ and control (58\%) cows. Similarly, Kennedy et al. (2009) reported that cows with 9-h grazing access grazed for a longer percentage of time $(81 \%)$ relative to time-unrestricted cows $(41 \%)$. These results suggest that the $1 \times 8$ cows in the present study were not limited in terms of access time at pasture per se, but may have been limited by the requirement to ruminate and rest that conflicted with their need to increase their rate of DMI while on pasture.

Similar DMI between $2 \times 4$ and control cows in the current study implies that $2 \times 4$ cows can maintain levels of milk production as per the control. The $10 \%$ reduction in EL milk yield for the $2 \times 4$ treatment compared with control can be partly attributed to the additional walking of $1.2 \mathrm{~km} /$ cow per day. This distance, at an estimated energy cost of $2.2 \mathrm{MJ}$ of $\mathrm{ME} / \mathrm{cow}$ per day, equates to approximately $0.4 \mathrm{~L}$ of milk/cow per day (Nicol and Brookes, 2007). Milk production losses attributed to the additional walking by $2 \times 4$ treatment cows could be reduced if the stand-off pad was located adjacent to the milking facility.

The similarity in LL pasture intake and milk production between restricted grazing treatments and the control may well be caused by the reduced intake rate requirement for LL cows restricted to an 8-h grazing period $(1.3 \mathrm{~kg}$ of $\mathrm{DM} / \mathrm{h})$ compared with EL cows (1.7 $\mathrm{kg}$ of $\mathrm{DM} / \mathrm{h}$ ) to maintain a DMI similar to the control. Given that cattle tend to reduce the amount of chewing during eating to increase intake rate (Parsons et al., 1994), the level of ingestive mastication for LL cows may have been higher than that for EL cows. Increasing the level of ingestive mastication may have increased the digestion and passage of grazed pasture and subsequently reduced the requirement for rest and rumination for LL cows restricted to an 8-h grazing period, enabling intake to be maintained relative to the control.

\section{Cow Welfare}

For the current study, BW and BCS change, pasture intake, and milk production did not differ between treatments. The only exception was pasture intake and milk production for the $1 \times 8$ treatment in EL. In this regard, under the conditions of the current study, to maintain productivity and animal welfare, pasture should be offered for longer than $8 \mathrm{~h}$ if pasture is offered for only 1 time period during the day in EL. However, cow productivity and welfare can be maintained when the 8 -h time on pasture is split equally into $2 \times$ 4 periods.

Despite the similarities in animal welfare parameters between restricted grazing access and the control in the experimental period, during the 10-d adaptation period the BW change for EL treatments was greater for $1 \times 8$ $(-3.8 \mathrm{~kg} /$ cow per day; $P<0.05)$ than $2 \times 4(-2.5 \mathrm{~kg} /$ cow per day) and control $(-1.8 \mathrm{~kg} /$ cow per day) cows, and the BW change for LL treatments was greater for 1 $\times 8(-1.8 \mathrm{~kg} /$ cow per day; $P<0.05)$ and $2 \times 4(-1.4$ $\mathrm{kg} /$ cow per day; $P<0.05)$ cows relative to control cows $(-0.9 \mathrm{~kg} / \mathrm{cow}$ per day). Thus, the time taken for cows to adjust to treatment suggests that short-term changes (1 wk or less) in pasture allocation, particularly for 1 $\times 8$, might have an effect on cow welfare. However, what is yet to be investigated is the ability of cows to increase the speed of adjustment to restricted grazing treatments if the same procedure is repeated after going back to 24-h grazing access (excluding milking).

Cow health and welfare (e.g., mastitis) have been improved with access to pasture when compared with loafing areas (Washburn et al., 2002). In the current study, the provision of a relatively large area per cow $\left(20 \mathrm{~m}^{2}\right)$ on the loafing area and adequate drainage of the bark surface may have created a dry environment for the cows and a similar SCC across treatments for EL and LL cows. This finding highlights the potential for management to maintain good animal health. Another management variable such as the poor maintenance of laneways increases the incidence of lameness in pasturebased systems (Lean et al., 2008). The risk of increased lameness for the $2 \times 4$ treatment in both EL and LL was higher than for the control treatment because of the additional distance walked $(1.2 \mathrm{~km} /$ cow per day $)$. As a consequence of the well-maintained races laneways used in the current trial, locomotion scores, as a proxy for lameness, were similarly low for all treatments.

\section{CONCLUSIONS}

Despite a change in grazing behavior for cows with restricted time on pasture, urination frequency remained constant compared with unrestricted time on pasture. As a result, decreasing the time on pasture and increasing time on a loafing pad increased the capture of urination events by $37 \%$ in EL and $32 \%$ in LL. Pasture intake rate in both EL and LL lactating cows increased to compensate for restricted time at pasture. Intake rate increased sufficiently for DMI and animal welfare to be maintained when pasture was offered as $2 \times 4$-h periods for cows in EL or for either $1 \times 8$-h period or $2 \times 4$-h periods in LL. These findings suggest that restricting grazing and consequently reducing urinations on pasture and laneways could be an effective mitigation strategy for decreasing nitrogen loss to the environment at high-risk times while maintaining cow production and welfare. 


\section{ACKNOWLEDGMENTS}

The authors thank DairyNZ Ltd. and New Zealand Ministry of Agriculture and Forestry Sustainable Farming Fund for funding. Urine sensors were developed within the Foundation for Research Science and Technology's Nitrogen and Taupo program C10X315. We express our gratitude to Gwyn Verkerk (Dairy NZ Ltd.) for technical assistance and Barbara Dow for the statistical analysis. Thanks also for the assistance and cooperation of John Siemelink, the Scott Farm staff, Jennie Burke, and the other DairyNZ Ltd. staff in Hamilton, New Zealand, who assisted with the trial.

\section{REFERENCES}

Betteridge, K., W. G. K. Andrewes, and J. R. Sedcole. 1986. Intake and excretion of nitrogen, potassium and phosphorus by grazing steers. J. Agric. Sci. 106:393-404.

Blackwell, M. B. 1993. Experiences with on-off grazing in early lactation on dairy farms in Northland. Proc. N.Z. Soc. Anim. Prod. 53:37-39.

Chilibroste, P., P. Soca, D. A. Mattiauda, and O. Bentancur. 2004 Incorporations of short terms fasting in grazing and feeding management strategies for cattle: An integrated approach. Proc II Int. Symp. Grassland Ecophysiology and Grazing Ecol. Curitiba, Brazil. J. Pizarro, ed. Universidade Federal do Parana, Curitiba, Brazil.

de Klein, C. A. M., and S. F. Ledgard. 2001. An analysis of environmental and economic implications of nil and restricted grazing systems designed to reduce nitrate leaching from New Zealand dairy farms. I. Nitrogen losses. N.Z. J. Agric. Res. 44:201-215.

Di, H. J., and K. C. Cameron. 2002. Nitrate leaching in temperate agroecosystems: Sources, factors and mitigating strategies. Nutr. Cycl. Agroecosyst. 46:237-256.

Forbes, J. M. 1995. Voluntary Food Intake and Diet Selection in Farm Animals. 1st ed. CAB International, Wallingford, UK.

Gregorini, P., C. E. F. Clark, J. G. Jago, C. B. Glassey, K. L. M. McLeod, and A. J. Romera. 2009. Restricting time at pasture: Effects on dairy cow herbage intake, foraging behavior, hungerrelated hormones, and metabolite concentration during the first grazing session. J. Dairy Sci. 92:4572-4580.

Hardison, W. A., H. L. Fisher, G. C. Graf, and N. R. Thompson. 1956 Some observations on the behavior of grazing lactating cows. J. Dairy Sci. 39:1735-1741.

Haynes, R. J., and P. H. Williams. 1993. Nutrient cycling and soil fertility in the grazed pasture ecosystem. Adv. Agron. 46:119 199.

Hutton, J. B., and O. F. Parker. 1966. The effect of grazing time and supplementary feeding of hay on production per cow in early lactation. Proc. N.Z. Soc. Anim. Prod. 26:71-85.

Jarvis, S. C., D. Scholefield, and B. Pain. 1995. Nitrogen cycling in grazing systems. Pages 381-419 in Nitrogen Fertilization in the Environment. P. E. Bacon, ed. Marcel Dekker, New York, NY.

Jonker, J. S., R. A. Kohn, and R. A. Erdman. 1998. Using milk urea nitrogen to predict nitrogen excretion and utilization efficiency in lactating dairy cattle. J. Dairy Sci. 81:2681-2692.

Kennedy, E., M. O'Donovan, M. McEvoy, and J. P. Murphy. 2009. Effect of restricted access time to pasture on dairy cow milk production, grazing behavior, and dry matter intake. J. Dairy Sci. 92:168-176.

Kohn, R. A., K. F. Kalscheur, and E. Russek-Cohen. 2002. Evaluation of models to estimate urinary nitrogen and expected milk urea nitrogen. J. Dairy Sci. 85:227-233.
Kristensen, T., F. Oudshoorn, L. Munksgaard, and K. Soegaard. 2007. Effect of time at pasture combined with restricted indoor feeding on production and behaviour in dairy cows. Anim. 1:439-448.

L'Hullier, P. J., and N. A. Thomson. 1988. Estimation of herbage mass in ryegrass/white clover dairy pasture. Proc. N.Z. Soc. Anim. Prod. 49:117-122.

Lean, I., C. T. Westwood, and M. C. Playford. 2008. Livestock disease threats associated with intensification of pastoral dairy farming. N. Z. Vet. J. 56:261-269.

Ledgard, S. F., and J. C. Menneer. 2005. Nitrate leaching in grazing systems and management strategies to reduce losses. Pages 79 82 in Proceedings of the Workshop Development in Fertiliser Application Technologies and Nutrient Management, Massey University, Palmerston North, New Zealand. Occasional Report No. 18. L. D. Curie and J. A. Hanly, ed. Massey University, Palmerston North, New Zealand.

Lindsay, C. L., J. A. Hanly, M. J. Hedley, and D. J. Horne. 2009. Controlling nitrogen and phosphorus loss from dairy farms using restricted grazing practices. Pages 295-302 in Proceedings of the Workshop Nutrient Management in a Rapidly Changing World, Massey University, Palmerston North, New Zealand. Fertilizer and Lime Research Centre Occasional Report No. 22. Massey University, Palmerston North, New Zealand.

Macdonald, K., and J. Roche. 2004. Condition Scoring Made Easy. DairyNZ, Hamilton, New Zealand.

Macdonald, K. A., and J. W. Penno. 1998. Management decision rules to optimise milksolids production on dairy farms. Proc. N.Z. Soc. Anim. Prod. 58:132-135.

McGowan, J. E., C. R. Burke, and J. G. Jago. 2007. Validation of a technology for objectively measuring behaviour in dairy cows and its application for oestrous detection. Proc. N.Z. Soc. Anim. Prod. 67:136-142.

Nicol, A. M., and I. M. Brookes. 2007. The metabolisable energy requirements of grazing livestock. Pages 151-172 in Pasture and Supplements for Grazing Animals. Occasional Publication No. 14. P. V. Rattray, I. M. Brookes, and A. M. Nicol, ed. NZ Soc. Anim. Prod., Hamilton, New Zealand.

O'Callaghan, K. A. P. J. C., and D. Y. Downham. 2003. Subjective and objective assessment of pain and discomfort due to lameness in dairy cattle. Anim. Welf. 12:605-610.

Oudshoorn, F. W., T. Kristensen, and E. Shahrak Nadimi. 2007. Dairy cow defecation and urination frequency and spatial distribution in relation to time-limited grazing. Livest. Sci. 113:62-73.

Parsons, A. J., J. H. M. Thornley, J. Newman, and P. D. Penning. 1994. A mechanistic model of some physical determinants of intake rate and diet selection in a two-species temperate grassland sward. Funct. Ecol. 8:187-204.

Payne, R. W., S. A. Harding, D. A. Murray, D. M. Soutar, D. B. Baird, A. L. Glaser, I. C. Channing, S. J. Welham, A. R. Gilmour R. Thompson, and R. Webster. 2008. GenStat. Release 11. VSN International, Hemel Hempstead, UK

Perez-Ramerez, E., R. Delagarde, and L. Delaby. 2008. Herbage intake and behavioural adaptation of grazing dairy cows by restricting time at pasture under two feeding regimens. Anim. 2:1384-1392.

Rowell, J. G., and D. E. Walters. 1976. Analysing data with repeated observations on each experimental unit. J. Agric. Sci. 87:423432.

Walters, R. J. K., and E. M. Evans. 1979. Evaluation of sward sampling technique for estimating herbage intakes by grazing sheep. Grass Forage Sci. 34:37-44.

Washburn, S. P., S. L. White, J. T. Green Jr., and G. A. Benson. 2002 Reproduction, mastitis, and body condition of seasonally calved Holstein and Jersey cows in confinement or pasture systems. J. Dairy Sci. 85:105-111.

World Organisation for Animal Health. 2008. Introduction to the recommendations for animal welfare. Pages 235-236 in Terrestrial Animal Health Code 2008. World Organisation for Animal Health, Paris, France. 